\title{
THE NOMINAL REMEMBRANCE OF BELIEVERS (LIVING AND DEAD) DURING THE EVENING SERVICES
}

\author{
Ph.D. Nicolae PREDA \\ Faculty of Orthodox Theology \\ "Justinian Patriarch" - University of Bucharest, \\ ROMANIA, \\ E-mail: preda_nicolae@hotmail.com
}

\begin{abstract}
Unfortunately, about the nominal remembrance of believers, aloud, during the evening service (that is, at Vespers) was written very little in our country, and not in a decisive manner. That is why I want to emphasize that the analysis of this theme calls for a much larger type of research, which the present study does not consider; However, we will try to point out some aspects of this usance. What can be said about this practice is that within the structures of Byzantine rite the remembrance of the living and the dead during the evening service has "survived" only in the rule of the Lity, which indeed, was "included" in the Vespers structure but also in the Compline's.
\end{abstract}

Keywords: Vespers; evening service; remembrance; believers; liturgical practice;

\section{THE NOMINAL REMEMBRANCE OF BELIEVERS (ALIVE AND DEAD) DURING THE EVENING SERVICES - OVERVIEW}

About the nominal remembrance of the faithful during the evening service (ie at Vespers) was written relatively little in our country, but not only ${ }^{1}$, and not in a decisive manner ${ }^{2}$. That is why we want to emphasize that the analysis of this theme calls for a much larger type of research, which the present study does not consider; It is therefore up to those interested to deepen, if they wish, all these characteristics.

However, we will try to analyze some aspects of the nominal remembrance of believers during the evening service (especially at Lity ${ }^{3}$ ), Recalling only a few things about

\footnotetext{
${ }^{1}$ Among the few studies that recall this usage, but not encountered in Byzantine rites, is the work of Fr. R. Taft, O Istorie a Liturghiei Sfântului Ioan Gură de Aur (A History of the Divine Liturgy of St. John Chrysostom), Volume IV. DIPTICELE. Translated by Cezar Login, Cluj-Napoca: Renaştrea Publishing, 2008; see also N. Preda, "Litia mică pentru cei morţi" - rânduială de tip eminamente palestinian ("Small Lity for deceased people” - practice of eminent Palestinian type), Bucharest: Granada Publishing House, 2016, p. 25.

${ }^{2}$ In our opinion, the lack of general interest on this issue is due first of all to the few existing sources, but also to the fact that the subject seems unfortunately, in the opinion of the specialists, not too important.

3 "LITY ( $\lambda \imath \imath \dot{\eta}, \dot{\eta}$ - liti, $i=$ Prayer, procession) - it is a religious service (Orthodox), which is performed in monasteries in the evening service (Vespers and Vigil) and more rarely in the morning service (Matins)", Fr. Prof. PhD. E. Branişte and Prof. Ecaterina Branişte, Dicţionar enciclopedic de cunoştinţe religioase (Encyclopaedic Dictionary of Religious Terms), Caransebeş: Diocesan Publishing, 2001, p. 261.
} 
the current practice and some uses, such as that mentioned by Saint Simeon of Thessalonica $(\dagger 1429)$, that of Lavra of Saint Savas $(\dagger 532)$ and that of Egeria ${ }^{4}$.

First of all, I would like to point out that what is undoubtedly about this practice is the fact that in Byzantine rites, the remembrance of the living and the dead $^{5}$ during the evening service "survived" only in the order of the Lity, which indeed, was "included" in the Vespers structure ${ }^{6}$ but also in the Compline's ${ }^{7}$.

\title{
2. THE NOMINAL REMEMBRANCE OF BELIEVERS (LIVING AND DEAD) DURING THE EVENING SERVICES - OUTSIDE BYZANTIUM
}

Note that the commemoration of the faithful (probably the living and the dead) during the evening service is also found in the liturgical structures outside Byzantium, such as, for example Egypt, as Fr. Robert Taft emphasizes, usage that he recalls in the context in which he speaks of the intercessions indicated in the liturgical anaphoral, which, in my opinion, is a decisive one:

\begin{abstract}
“... we must bear in mind that the Egyptian liturgical forms are interspersed with prayers of intercession, often using a "standard" liturgical vocabulary including a set of expressions common to the liturgical Greek language of all traditions, not only within the long anaphoral precessions before Sanctus $^{8}$ and diptychs ${ }^{9}$ crrectly named so, but also in the Enarx and in the Liturgy of the Word ${ }^{10}$ within the Eucharist, not to mention the Incense sacrifice of Morning and Evening" $" 11$.
\end{abstract}

\footnotetext{
${ }^{4}$ See Edward G. Farrugia, Dicţionarul Enciclopedic al Răsăritului creştin (Encyclopedic Dictionary of the Christian East). Translated from Italian by Adrian Popescu, Vasile Rus, Ioan Muntean and Andrei Mărcuş, Târgu Lăpuş: Galaxia Gutenberg Publishing, 2005, pp. 264-265.

${ }^{5}$ It's more about a "request" In which are also remembered those who are asleep in the general way, a section that appears in the litany of Lity, as we shall see.

${ }^{6}$ But if we observe the structure of the evening service explained by Egeria, we see that the procession (Lity) was actually part of the evening service (ie, the service of Vespers), and therefore, had no need to be "included" or "framed"; Unfortunately, about the evolution of these liturgical structures and how they "migrated", as we've already mentioned, little was written, which is why it is quite difficult to express fair assumptions.

${ }^{7}$ Cf. Fr. Prof. PhD. E. Branişte, Liturgica Specială pentru institutele teologice (Special Liturgy for Theological Institutes), Bucharest: Publishing House of the Bible and Mission Institute of the Romanian Orthodox Church, $1985^{2}$, p. 76.

8 “SANCTUS. - Chant de louanges et de triomphe, exécuté par le chœur après la préface de la Messe, et récité par le Célébrant et ses Ministres", R. Lesage, Dictionnaire pratique de Liturgie romaine, Paris: Bonne Presse, 1952 , p. 962.

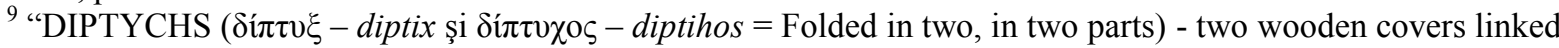
with hinges that can close like a book. On the inner parts of these covers are painted icons or are written the names of the living and of the dead for whom the priest prays at the Divine Liturgy, After completing the great prayer of the Holy Sacrifice (the Anaphora). This prayer of general intercession, for the living and the dead, which the priest does after the Epiclesis (the Eucharistic Prayer) bears the name of diptychs (from the fact that the names of those they pray for are registered in these registers, in the form of closed covers)", Fr. Prof. PhD. E. Branişte and Prof. Ecaterina Branişte, Dicţionar enciclopedic... (Encyclopedic Dictionary...), pp. 139-140.

10 "La liturgie de la Parole constitue à présent le premier des grands pôles qui forment l'ossature de la messe, avec cet autre pôle, essentiel: la liturgie du sacrifice (à partir de l'offertoire)", Dictionnaire Encyclopédique de la Liturgie, sous la direction de Domenico Sartore et Achille M. Triacca. Adaptation française sous la direction d'Henri Delhougne. Volume I. A-L, Turnhout: Brepols, 1992, p. 367; In the Byzantine cult, The Liturgy of the Word Is equivalent to the first part of the Byzantine Liturgy called The Liturgy of the Catechumens.

${ }^{11}$ Robert F. Taft, O Istorie a Liturghiei Sfântului Ioan Gură de Aur. Volumul IV. DIPTICELE... (A History of the Divine Liturgy of St. John Chrysostom. Volume IV. DIPTYCHS...), p. 65.
} 
About this liturgical structure called "The Incense Sacrifice of Morning and Evening" ("l'offerta mattutina e serale dell'incenso") ${ }^{12}$, father Robert Taft $^{13}$ and G. Winkler $^{14}$ say, on the basis of the structure of these ordinances, that they originate from the ancient liturgical forms of cathedral type (Or more accurately they are "reminiscences" of an old cathedral-type order) ${ }^{15}$; Unfortunately, father Robert Taft does not give any insight into the cathedral-type tradition to which these structures belong.

In the composition of this order of service ("The Incense Sacrifice of Morning and Evening") we compare therefore topics such as "Grande intercessione"16 and two other categories, which indicate "short intercessions" ("Incensazione dell'altare, con brevi intercessioni" and "Incensazione e brevi intercessioni") ${ }^{17}$, at the beginning and at the end of the order, both closely related to the so-called incest ritual (that is, immediately after it) ${ }^{18}$.

\section{THE NOMINAL REMEMBRANCE OF BELIEVERS (ALIVE AND DEAD) DURING THE EVENING SERVICES OF BYZANTINE RITE}

\section{A) Lavra of St. Savas}

Returning to the Byzantine ritual structures, we would like to point out that in the old practice of the Lavra of Saint Savas it is recalled, the remembrance of both the living and the dead in Lity [see Sinai Codices $1096^{19}$ (dated in the 14 th century) ${ }^{20}$; This usage ${ }^{21}$, seems to be at the origin of the current practice which has "suffered", it is true, some significant changes in that the remembrance of the living is made only in Lity ${ }^{22}$, and of the dead only at Lity for the dead.

${ }^{12}$ Robert F. Taft, La liturgia delle ore in oriente e occidente. Le origini dell'ufficio divino e il suo significato per oggi, Roma: Edizioni Lipa, 2001, p. 312.

13 “Questo ufficio contiene ciò che sembrano essere resti di uffici di cattedrale piú antichi...”, Ibid., p. 313.

14 "Winkler ha identificato nell'offerta serale copta dell'incenso il residuo di un antico vespro di cattedrale", Ibid., p. 316; see also page 316, note 24.

${ }^{15}$ Note that the particularities of these structures are recorded by Fr. R. Taft In a subchapter entitled: "II. RESTI DI CATTEDRALE” (cf. La liturgia delle ore in oriente e occidente..., p. 313).

${ }^{16}$ Robert F. Taft, La liturgia delle ore in oriente e occidente..., p. 313, row 7; This intercession called also "great" follows the incest rituali.

${ }^{17}$ Robert F. Taft, La liturgia delle ore in oriente e occidente..., p. 313, row 6 and respectively 23.

${ }^{18} \mathrm{Cf}$. Robert F. Taft, La liturgia delle ore in oriente e occidente..., p. 313.

19 "1096. Tvлıкóv. Cod. membr. 20X14; 3 centim. saec. XIV”, V. Gardthausen, Catalogus codicum Graecorum Sinaiticorum, Oxonii: E Typographeo Clarendoniano, 1886, p. 222; "Sinai 1096 (XII-XIII centuries)", N. Uspensky, Slujba de seară în Biserica Ortodoxă (Evening Service in the Orthodox Church). Translated by

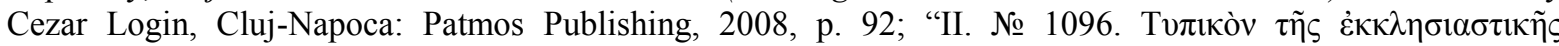

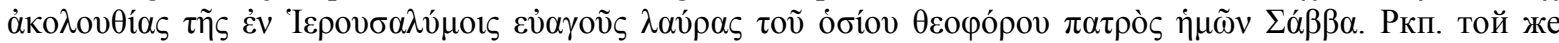
библ. [Архимандритъ Антонинъ опредьляетъ XII-XIII в.]”, А. Дмитр1евский, Описанле литургическихъ рукописей, хранящихся въ библьотекахъ Православнаго Востока. Томъ III. Тәлıко́, Петрогрдъ: Типографія В. Ө. Киршбаума, 1917, р. 20.

20 "Then the priest remembers and reads the names of the living and dead Christ lovers which are written in the diptychs", N. Uspensky, Slujba de seară... (The Evening Service...), p. 93.

${ }^{21}$ The old practice of mentioning during Lity "of the living and of the dead", written in the Typikon from St. Sava Monastery, is, fortunately, also remembered by the so-called Great Efchológion, edited in Athens by N.

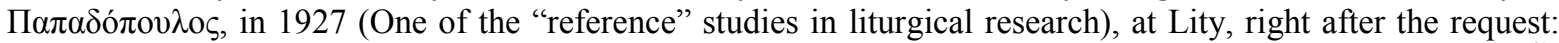

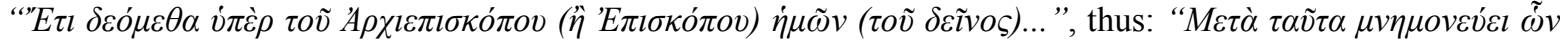

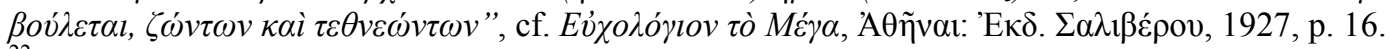

${ }^{22}$ In the Romanian Hieratikon, the remembrance of "the living" appears at Lity, after the request: "We still

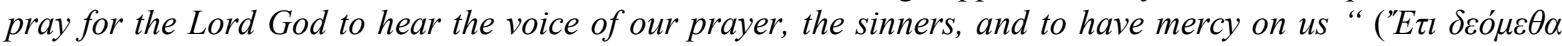

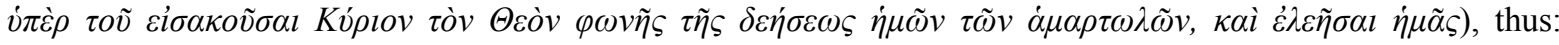

"Then he reads, in low voice, the names of the living", cf. Liturghier (Hieratikon), Bucharest: Publishing House of the Bible and Mission Institute of the Romanian Orthodox Church, 2000, p. 51; the form of the last 


\section{B) Service books (the Hieratikon)}

Reminiscences of the old liturgical practice of the Church (ie, the Savas' type), concerning the "remembrance of the living and of the dea" at Lity, are found, "to a certain moment", in the earlier editions of the Romanian Hieratikon, thus:

a) "Then low he remembers who he wants, alive or dead" $d^{23 ، 24}$;

b) "Then low he remembers who he wants, alive and dead" ${ }^{25.26}$;

c) "(The priest remembers those who have brought the Lity and who he wants) ${ }^{27}$ (228.

Note that starting with the 1937 edition of the Hieratikon, the Lity already appears as a "separate subchapter" (pp. 39-48), not as in the previous editions (for example 1921, 1927), included in the Vespers, and will remain so until the last edition of the Hieratikon (2012).

Moreover, it can be seen in the books of worship (Hieratikon) the "unusual" modification of the Lety structure (we refer first and foremost to the evolution of nominal remembrances of living and dead believers as structural elements), "operated" Probably for less known reasons and without taking into account, of course, the "healthy development" and the primary significance of this order.

C) Saint Simeon of Thessalonica

It is also very important to mention Saint Simeon of Thessalonica, recalling in the context in which he describes the Lity, the remembrance of "all believers", not to mention

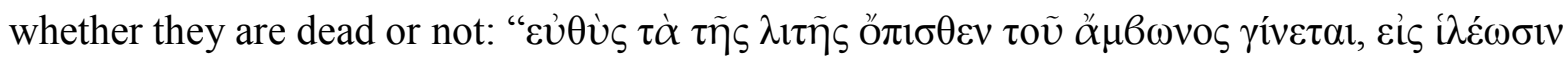

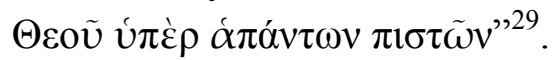

edition of the Romanian Hieratikon is: "[If he wants to mention the living, he will add the request: We still pray for mercy, life, peace, health, salvation, research, forgiveness and forgiveness of the sins of God's servants (N) and to forgive them for all their voluntary and involuntary sins. And the choir answers: Kyrie eleison (three times)]", cf. Liturghier (Hieratikon), Bucharest: Publishing House of the Biblical Institute and Orthodox Mission, 2012, p. 60; to note that today's remembrance of "the living" at Lity Tends to become of "relative" use, but which "seeks" to still preserve, "the old structure" (See the form of the earlier editions of the Hieratikon, for example the one in 1937).

${ }^{23}$ Dumnezeeştile Liturghii ale Sfinţilor noştri Parinţi: Ioan Gură de Aur, Vasilie cel Mare şi Grigorie Dialogul (Divine Liturgies of Our Holy Fathers: John Chrysostom, the Basil the Great and Gregory the Dialogue), Bucharest: The Printing House of the Church Books, $1921^{5}$, p. 33

${ }^{24}$ The remembrance of "the living and the dead" appears at Lity, after the request: "We still pray that the Lord God will hear the voice of our prayer, the sinners, and will have mercy on us ", cf. Dumnezeeştile Liturghii... (Divine Liturgies...) (Bucharest, 1921), p. 33.

${ }^{25}$ Dumnezeeştile Liturghii ale Sfinţilor noştrii Părinţi: Ioan Gură de Aur, Vasile cel Mare şi Grigorie Dialogul (Divine Liturgies of Our Holy Fathers: John Chrysostom, the Basil the Great and Gregory the Dialogue), Church Typography of the Holy Cernica Monastery, $1927^{5}$, p. 37.

${ }^{26}$ The remembrance of "the living and the dead" appears at Lity, after the request: "We still pray that the Lord God will hear the voice of our prayer, the sinners, and will have mercy on us ", cf. Dumnezeeştile Liturghii... (Divine Liturgies...) (The Holy Monastery of Cernica, 1927), pp. 36-37.

${ }^{27}$ Sfintele și dumnezeieştile Liturghii ale sfinţilor noştri Părinţi: Ioan Gurădeaur Vasilie cel Mare şi Grigorie Dialogul (Divine Liturgies of Our Holy Fathers: John Chrysostom, the Basil the Great and Gregory the Dialogue), Bucharest: The Printing House of the Church Books, 1937, p. 41.

${ }^{28}$ The remembrance "of those who brought the Lity etc." is shown in Lity within the request: "We still pray for the mercy, life, peace, health, salvation, research, and forgiveness of the sins of God's servants the glorious Christians...”, cf. Sfintele și dumnezeieştile Liturghii... (Divine Liturgies...) (Bucharest, 1937), p. 41; Unfortunately, the expression "and who he wants" is not very clear; it could easily include the dead.

${ }^{29}$ PG 155, p. 633; "And Lity is performed immediately after Anvon (!), as to God tame for all believers", T. Teodorescu, Saint Simeon the Archbishop of Thessalonica. Treaty of All Dogmas of Our Orthodox Faith, after the True Principles Set by Our Lord Jesus Christ and His Followers. Reprinted after the original, translated 
The mention of Saint Simeon of Thessalonica, although at first glance it would seem "poor", if we think strictly to the practical part of the ordinance ${ }^{30}$, nevertheless, it presents two essential aspects (realities), such as the reason of the Lity (taht of taming God) And the concrete indication of those who share the "mercy" of God (that is all believers) ${ }^{31}$.

D) Jerusalem (Egeria)

A last mention of the remembrance of the believers during the evening service (Vespers), which we have already mentioned, is that given by Egeria; unfortunately, not even this old exposition specifies whether during the evening service were mentioned the living as well as the dead.

In order to "complete" the "form" of this old practice, we think we should also remember something about the current use, according to which during the Lity are mentioned only the living.

\section{THE CURRENT LITURGICAL PRACTICE OF THE SINGULAR REMEMBRANCE OF THE LIVING DURING THE LITY}

Therefore, in the context of the analysis of the current practice, it must be stated, first of all, that the remembrance of the faithful (the living) has "survived" until today in the structure of the Lity, although it remains inexplicable how was "dropped" the primary practice of remembering all believers (alive and dead) during the evening service; as to how the remembrance of the dead was "transferred" from the Lity to the Lity for the dead (a "somewhat" recent liturgical order) unfortunately, there is no exact exposure either in springs or in specialized studies.

In our opinion, the actual practice of remembrance within the evening service (those from the Lity), which seems to "lose" from its former complexity, could be the result of the so-called evolution of liturgical forms (structures) from complex to simple, hypothesis "launched" in the liturgical research by C. Giraudo, who considers the long and complex structures as primary ones ${ }^{32}$.

Nevertheless, the old liturgical practice of remembering the living and the dead during Lity is a fundamental aspect of the worship ordinances, especially since we find it, as we have said, until today in the structure of Lity.

As far as the current practice of the Lity is concerned, we would like to draw attention to a fact that specialists emphasize very little or not at all, and which, for this reason, it will impose itself in the present practice, namely the nominal remembrance during Lity only of the living, and not of those who are dead, as in primary practice (see the Lity ordinance recorded in Codex Sinai 1096), and which seems to be inconsistent with the structure of the Lity itself, in which the following text (request) appears:

\footnotetext{
"We still pray (...) for the rest, relief, forgiveness of sins, and the joyful remembrance of all those who, before, have moved to the right faith, our parents and brothers and sisters who rest here and everywhere, ${ }^{33}$.
}

from Greek in 1765, and amendated in the days of the High Lord of the United Principalities of Romania in the year 1865, Alexandru Ioan I, Bucharest: Toma Teodorescu Typography, 1865, p. 228.

${ }^{30}$ Note that Saint Simeon does not give here either the structure of the Lity (perhaps well-known at that time) nor does he detail the type of nominal remembrance, probably for the same reasons.

${ }^{31}$ In our opinion, this phrase can encompass both the living and the dead.

${ }^{32}$ L'epiclesi eucaristica. Proposta per una soluzione "ortodossa" della controversia tra Oriente e Occidente, Roma: Dispense Pontificio Istituto Orientale, 2002-2003, p. 22, note 3.

${ }^{33}$ Liturghier (Hieratikon), Bucharest, 2000, p. 50. 
In our opinion, this request, which attests, on the one hand, the length of this service ordinance, but also that its structure is an authentic one that retains primary elements, clearly depicts the "primary" vision of the Church Fathers on the Lity, which includes all believers, a perspective later portrayed by Saint Simeon of Thessalonica, who considers the Lity's ${ }^{34}$ ultimate reason to be "to tame God for all believers" 35 .

\section{THE LITY AND THE LITY FOR THE DEAD - "CLUES" OF A COMMON INITIAL LITURGICAL STRUCTURE}

The reason for which the Church considered that a separate ordinance should appear for the dead, that is what the current books of worship call the Lity for the dead, has its foundation, without a doubt, in the old practice from the Lavra of Saint Savas, although the significance of the present demand inserted into the structure of the Lity, in which the dead are also mentioned, should not be ignored.

In conclusion, it should be noted that what we definitely miss is the way in which the "actual" transition from the usual Lity from the church porch will take place (originally, at the tomb of Saint Sava), the Savas' type monasteries, during the Lity for the dead also done in the porch of the church.

Therefore it remains posterior studies to confirm or refute this hypothesis, which seems to have a fair reason, given the old structures and ordinances of service, as well as the current ones.

Equally important appear to be the insights on both the place and the time of the socalled Lity for the dead (ordinance which will include par excellence nominal remembrance of the dead), as well as more precise indication of liturgical days in which it could have been as well as more precise indication of the liturgical days in which it could have been performed $^{36}$, particularities mentioned otherwise by The Great Typikon of Saint Sava, but about which, unfortunately, other sources and specialized studies do not remember anything.

The one who signals some decisive indications about the time and place of the performance of an ordinance named by him "as if for the Lity" is Saint Simeon of Thessalonica; these particularities could "illustrate", in our opinion, if not the evolution of these structures, at least a "form" of the transition from one ordinance structure to anothera, that is, from the Lity of the church feasts and from Saturday evening to the so-called "Lity" of the ordinary days (a structure we do not know much about):

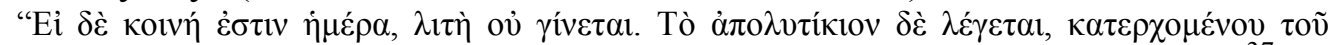

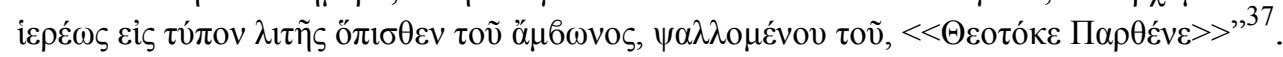

\footnotetext{
${ }^{34}$ Talking about the structure and primary meaning of the Lity, Fr. Prof. E. Branişte highlights new meanings: "The old prayers of the procession lities of the former Christendom have been preserved in use so far, but were included in the divine service in churches and became the first part of today's Lity. They have an accentuated penitential character, that is, they express with persistence the feeling of repentance and prayer for forgiveness of sins, because in the conception of the ancient Christians, the misfortunes, for the removal of which they pray, were considered to be the consequences or punishments for sins", Liturgica Specială... (Special Liturgy...), p. 82.

35 T. Teodorescu, Sfântul Simeon Arhiepiscopul Tesalonicului... (Saint Simeon the Archbishop of Thessalonica...), p. 228.

${ }^{36}$ Perhaps during the ordinary days after Vespers, as already "anticipated" by St. Simeon of Thessalonica, in the morning after Matins (indication of religious books) or after the First Hour, as recorded by The Great Typikon of Saint Sava.

${ }^{37}$ PG 155, p. 633; <<And if it is ordinary day there is no Lity, but the Troparion is said, when the priest descended behind the pulpit as if for the Lity and singing: "Mother of God, Virgin" $>>$, T. Teodorescu, Sfântul Simeon Arhiepiscopul Tesalonicului... (Saint Simeon the Archbishop of Thessalonica...), p. 228.
} 
This "service structure" that Saint Simeon recalls may be an intermediate stage in the evolution of the Ordinance of the Lity, but about the form of this "procession", very interesting, Saint Simeon does not give us details, but he simply calls it "as if for the Lity"; moreover, the troparion that he indicates, "providentially", is precisely the one that is being sung during Lity nowadays, that is "Mother of God, Virgin..."; what needs to be emphasized is that in this context St. Simeon no longer remembers any nominal remembrance of believers.

In our opinion, it is very likely that this very structure (procession) of the ordinary day has been the origin of the so-called Lity for the dead, which is also being performed during the ordinary days, or it may represent a "typology" of the "processions" of the past which were based on the processions from the Lity; however, it is very difficult to say which of these structures were the primary ones.

Another interesting detail that Saint Simeon records is the place where the "processions" indicated by him used to take place (both those from Lity and those from the procession "as if for the Lity"), both being performed behind ${ }^{38}$ the pulpit".

Even though we can not precisely determine the space indicated by the phrase used by Saint Simeon when he speaks of the place for performing the Lity ("behind the pulpit"), we think, however, that it is very likely the church's narthex; but the secondary meaning of the word "pulpit" can not be ignored either, which in the old books of service, as Fr. Prof. Ene Branişte notices, meant narthex or porch; surprisingly, here too, the word "pulpit" (meaning narthex or porch) is also used in the context in which the ordinance of the Lity is mentioned $^{40}$.

Unfortunately, our statements remain only simple assumptions, given the lack of obvious clues from sources and studies, which is why those interested could analyze these topics in the future in order to bring to light the full meaning of these ordinances and services structures.

In other respects, we would like to point out that a testimony of the "transition" we have mentioned in the precedence (probably another stage in the evolution of these structures) or, why not, a reminiscence of the old common practice of the "processions" from Lity, can be also the alternative singing of the sticheron from the Lity at the Lity for the dead:

"In the evening after the dismissal of the Vespers, or in the morning after the dismissal of the Matins, and after the church singers say: For many years, the priest immediately takes the censer with incense and the epitrachelion and the eclesiarch takes the candlestick with the candle lit, walking in front of the priest; and when the church singers walk, following them,

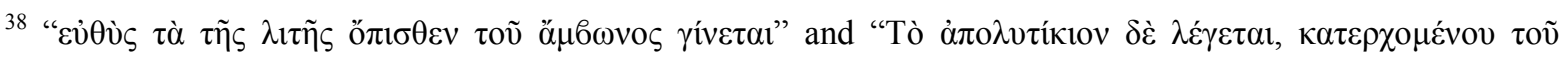

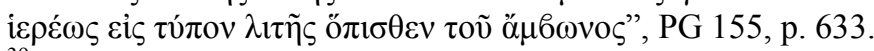

$39<<$ PULPIT ( $\alpha \mu \beta \omega v, \dot{o}-$ amvon, d. $\alpha \dot{\alpha} \alpha \beta \alpha i v \omega$ - anavaino = to climb, to get up) - is today a small balcony on the north wall of the church, inside the nave, closer or farther from the altar, placed at some height, serving for church servants, who go up in the pulpit to read the gospel and preach the sermon (...) Amvon/ Pulpit is also called the middle of the enlarged sole; in the old books of service, pulpit meant a narthex or a veranda, porch (v. Mineiul pe Martie, Buda, 1805, f. 94, r. col. 12: "We go out in the pulpit and perform the Lity" >>, Fr. Prof. PhD. E. Branişte and Prof. Ecaterina Branişte, Dicţionar enciclopedic... (Encyclopedic Dictionary...), pp. 29 30 .

40 “And after Glory to God's highest: We go out in the Pulpit, and we perform the Lity, as accustomed", March Menaion, Buda: the Princely Publishing House of the University of Peșta, 1805, p. 94r, lines 19-21; this is the case of the Lity ordinance from March 25th (the Annunciation), ("at night"), being included in the Service of the Great Compline, cf. March Menaion, Buda: the Princely Publishing House of the University of Peșta, 1805, p. $94 \mathrm{r}$.
} 
they sing a dismissal, which is from the Lity; and another time, another dismissal, changing them one after the other, also from the Lity of the patron saint who is celebrated. And reaching the porch of the Church"

Note that this peculiarity of the alternative singing of the dismissals from the Lity of the patron saint of the Church during the procession of the Lity for the dead, is not explicitly recorded in The Great Typikon ${ }^{42}$, although it is quite new in its own way, but appears in our books of worship, such as Panikhida ${ }^{43}$. But where it came from, it's hard to say.

\section{THE REAL SIGNIFICANCE OF THE CURRENT LITURGICAL PRACTICE OF NOMINAL REMEMBRANCE OF BELIEVERS DURING LITY}

Returning to the current practice during the Lity and its understanding, We ask how much more we perceive from the primary "vision" of the Fathers of the Church, since this fundamental characteristic of the Lity, to includes all believers, "seems" not to say too many to the Christians today, although our Church preserves, to a certain degree, all these structures (ordinances).

I believe that only a healthy catechesis about these liturgical realities, as if "forgotten" today, could bring extra light into their understanding.

\section{CONCLUSION}

On the nominal remembrance of believers, aloud, during the evening service (ie, at Vespers) was unfortunately very little written in our country, and not in a decisive manner.

What we can say, without a doubt, about this practice, is that in the Byzantine rite structures, the remembrance of the living and the dead during the evening service "survived" only in the ordinance of the Lity, which, rightly, was "included" in the structure of Vespers, but also in that of Compline's.

Also, the ancient liturgical practice of the remembrance of the living and the dead during Lity is a fundamental aspect of the worship ordinances, especially as we find it, as we have said, until today within the structure of the Lity.

Regarding the current practice during the Lity and its understanding, we wonder how much we perceive from the primary "vision" of the Fathers of the Church, since this fundamental characteristic of the Lity, to include all believers, "seems" not to say too many to the Christians today; in our opinion, this usage, which seems to "lose" from its former complexity, could be the result of the so-called evolution of liturgical forms (structures) from complex to simple.

\footnotetext{
${ }^{41}$ Panikhida or Memorial service together with the Little Lity. In which all the ordinance is encompassed when memorial is given to the dead, Bucharest: Printing House of Church Books, 1922 ${ }^{3}$, p. 5.

${ }^{42}$ Even if we do not know exactly where this usage was "borrowed" from, it should be noted that from the context of many such statements, recorded in the Great Typikon, one could "infer" this practice without any difficulty, as we will see.

43 "Panikhida is also called the church book embodying the funeral service and other services that are done for the dead (memorial services); originally this book was part of the Euchologion”, Fr. Prof. PhD. E. Branişte and Prof. Ecaterina Branişte, Dicţionar enciclopedic... (Encyclopedic Dictionary...), p. 337.
} 


\section{BIBLIOGRAPHY:}

[1] Branişte, E., Fr. Prof. PhD and Prof. Ecaterina Branişte, Dicţionar enciclopedic de cunoştinţe religioase (Encyclopaedic Dictionary of Religious Terms), Caransebeș: Diocesan Publishing, 2001 [2] Branişte, E., Fr. Prof. PhD. Liturgica Specială pentru institutele teologice (Special Liturgy for Theological Institutes), Bucharest: Publishing House of the Bible and Mission Institute of the Romanian Orthodox Church, $1985^{2}$

[3] Dictionnaire Encyclopédique de la Liturgie, sous la direction de Domenico Sartore et Achille M. Triacca. Adaptation française sous la direction d'Henri Delhougne. Volume I. A-L, Turnhout: Brepols, 1992

[4] Дмитревский, А. Описанце литургическихъ рукописей, хранящихся въ библютекахъ Православнаго Востока. Томъ III. Тvлıко́, Петрогрдъ: Типографія В. Ө. Киршбаума, 1917

[5] Dumnezeeştile Liturghii ale Sfinţilor noştri Parinţi: Ioan Gură de Aur, Vasilie cel Mare şi Grigorie Dialogul (Divine Liturgies of Our Holy Fathers: John Chrysostom, the Basil the Great and Gregory the Dialogue), Bucharest: The Printing House of the Church Books, $1921^{5}$

[6] Dumnezeeştile Liturghii ale Sfinţ̧ilor noştrii Părinţi: Ioan Gură de Aur, Vasile cel Mare şi Grigorie Dialogul (Divine Liturgies of Our Holy Fathers: John Chrysostom, the Basil the Great and Gregory the Dialogue), Church Typography of the Holy Cernica Monastery, $1927^{5}$

[7] Farrugia, Edward G. Dictionarul Enciclopedic al Răsăritului creştin (Encyclopedic Dictionary of the Christian East). Translated from Italian by Adrian Popescu, Vasile Rus, Ioan Muntean and Andrei Mărcuş, Târgu Lăpuş: Galaxia Gutenberg Publishing, 2005

[8] Gardthausen, V. Catalogus codicum Graecorum Sinaiticorum, Oxonii: E Typographeo Clarendoniano, 1886

[9] Giraudo, C. L'epiclesi eucaristica. Proposta per una soluzione "ortodossa" della controversia tra Oriente e Occidente, Roma: Dispense Pontificio Istituto Orientale, 2002-2003

[10] Lesage, R. Dictionnaire pratique de Liturgie romaine, Paris: Bonne Presse, 1952

[11] Liturghier (Hieratikon), Bucharest: Publishing House of the Bible and Mission Institute of the Romanian Orthodox Church, 2000

[12] Liturghier (Hieratikon), Bucharest: Publishing House of the Biblical Institute and Orthodox Mission, 2012

[13] March Menaion, Buda: the Princely Publishing House of the University of Peșta, 1805

[14] Panikhida or Memorial service together with the Little Lity. In which all the ordinance is encompassed when memorial is given to the dead, Bucharest: Printing House of Church Books, $1922^{3}$

[15] Sfintele şi dumnezeieştile Liturghii ale sfinţilor noştri Părinţi: Ioan Gurădeaur Vasilie cel Mare şi Grigorie Dialogul (Divine Liturgies of Our Holy Fathers: John Chrysostom, the Basil the Great and Gregory the Dialogue), Bucharest: The Printing House of the Church Books, 1937

[16] Taft, R. F. La liturgia delle ore in oriente e occidente. Le origini dell'ufficio divino e il suo significato per oggi, Roma: Edizioni Lipa, 2001

[17] Taft, R. F. O Istorie a Liturghiei Sfântului Ioan Gură de Aur (A History of the Divine Liturgy of St. John Chrysostom), Volume IV. DIPTICELE. Translated by Cezar Login, Cluj-Napoca: Renaştrea Publishing, 2008

[18] Teodorescu, T. Saint Simeon the Archbishop of Thessalonica. Treaty of All Dogmas of Our Orthodox Faith, after the True Principles Set by Our Lord Jesus Christ and His Followers. Reprinted after the original, translated from Greek in 1765, and amendated in the days of the High Lord of the United Principalities of Romania in the year 1865, Alexandru Ioan I, Bucharest: Toma Teodorescu Typography, 1865

[19] Uspensky, N. Slujba de seară în Biserica Ortodoxă (Evening Service in the Orthodox Church). Translated by Cezar Login, Cluj-Napoca: Patmos Publishing, 2008

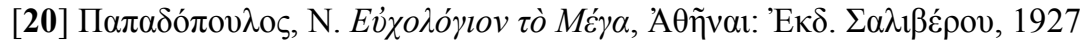

